\title{
Correction to: Periodontal health in an indigenous Sámi population in Northern Norway: a cross-sectional study
}

Ann-Kristine Sara Bongo 1,2,3* , Magritt Brustad ${ }^{1}$, Nils Oscarson² and Birgitta Jönsson ${ }^{1,4}$

\section{Correction to: BMC Oral Health (2020) 20:104 https://doi.org/10.1186/s12903-020-01098-3}

Following publication of the original article [1], the authors identified an error in the Table 4 .

The correct table is given below:

Furthermore, due to those errors in Table 4, following corrections are related to the text:

1. Statistical analysis on page 3, paragraph 4: 'RBL and $\mathrm{PD}$ are presented as percent and proportions (SE) of affected sites and teeth for the total study population, stratified by age group and ethnicity. Differences between groups were assessed with $\chi^{2}$-test and $t$-test;

2. Results on page 4 under subtitle 'Prevalence and distribution', last sentence: 'In total (18-75 years), a higher proportion of Sámi had one or more $\mathrm{PD} \geq 6 \mathrm{~mm}$ compared to non-Sámi $(p<0.05$.);
3. Discussion on page 5, third paragraph, second sentence: 'A larger proportion of Sámi had one or more $\mathrm{PD} \geq 6 \mathrm{~mm}$ compared to non-Sámi, with no ethnic difference in prevalence of $\mathrm{PD} \geq 4 \mathrm{~mm}$ and $\mathrm{PD} \geq 6 \mathrm{~mm}$;

4. Abstract on page 1 under results, last sentence: 'A higher proportion of Sámi had one or more $\mathrm{PD} \geq 6 \mathrm{~mm}$ than the non-Sámi $(p<0.05)$ ';

Abstract on page 1 under conclusion: 'People with Sámi ethnicity had deep periodontal pockets and an increased odds of having severe stages of periodontitis.

The original article has been updated.

(c) The Author(s) 2021. Open Access This article is licensed under a Creative Commons Attribution 4.0 International License, which permits use, sharing, adaptation, distribution and reproduction in any medium or format, as long as you give appropriate credit to the original author(s) and the source, provide a link to the Creative Commons licence, and indicate if changes were made. The images or other third party material in this article are included in the article's Creative Commons licence, unless indicated otherwise in a credit line to the material. If material is not included in the article's Creative Commons licence and your intended use is not permitted by statutory regulation or exceeds the permitted use, you will need to obtain permission directly from the copyright holder. To view a copy of this licence, visit http://creativecommons.org/licenses/by/4.0/. The Creative Commons Public Domain Dedication waiver (http://creativeco mmons.org/publicdomain/zero/1.0/) applies to the data made available in this article, unless otherwise stated in a credit line to the data. 
Table 4 Prevalence and extent of radiographic bone loss and periodontal pocked depth by age group, ethnicity and in total

\begin{tabular}{|c|c|c|c|c|c|c|c|c|c|c|}
\hline \multirow[t]{2}{*}{ Periodontal measurements } & \multicolumn{8}{|c|}{ Age Groups (years) } & \multirow{2}{*}{\multicolumn{2}{|c|}{$\frac{\text { Total }}{18-75}$}} \\
\hline & $18-34$ & & $35-49$ & & $50-64$ & & $65-75$ & & & \\
\hline Ethnicity & Sámi & Non-Sámi & Sámi & Non-Sámi & Sámi & Non-Sámi & Sámi & Non-Sámi & Sámi & Non-Sámi \\
\hline Number of individuals & 313 & 106 & 435 & 252 & 468 & 241 & 165 & 98 & 1381 & 697 \\
\hline \multicolumn{11}{|l|}{$\mathrm{RBL}$, proportions ${ }^{\mathrm{a}}$} \\
\hline RBL 15-33\% & 3.8 & 5.7 & 32.6 & 25.0 & 59.4 & 53.5 & 53.9 & 57.1 & 37.7 & 36.4 \\
\hline $\mathrm{RBL}>33 \%$ & 0.3 & 0.0 & 3.5 & 5.6 & 23.3 & 21.2 & 25.5 & 25.5 & 12.1 & 12.9 \\
\hline \multicolumn{11}{|l|}{ PD, proportions ${ }^{a}$} \\
\hline One or more $P D \geq 4 \mathrm{~mm}$ & 40.6 & 40.6 & 63.7 & 56.4 & 71.6 & 63.1 & 73.3 & 81.6 & 62.3 & 59.8 \\
\hline One or more $P D \geq 6 \mathrm{~mm}$ & 5.1 & 5.7 & 16.1 & 10.3 & 29.1 & 19.9 & 27.3 & 27.5 & 19.4 & 15.6 \\
\hline \multicolumn{11}{|l|}{$P D$, mean $(S E)^{b}$} \\
\hline \multicolumn{11}{|l|}{ Proportions of sites/mouth } \\
\hline $\mathrm{PD} \geq 4 \mathrm{~mm}$ & $3.5(0.4)$ & $3.8(0.7)$ & $7.7(0.5)$ & $6.8(0.7)$ & $10.5(0.7)$ & $10.1(1.0)$ & $8.8(0.9)$ & $11.7(1.4)$ & $8.0(0.3)$ & $8.2(0.5)$ \\
\hline$P D \geq 6 \mathrm{~mm}$ & $0.2(0.0)$ & $0.1(0.1)$ & $0.5(0.1)$ & $0.4(0.1)$ & $1.3(0.2)$ & $1.1(0.2)$ & $1.2(0.2)$ & $1.2(0.3)$ & $0.8(0.1)$ & $0.7(0.1)$ \\
\hline
\end{tabular}

$\mathrm{RBL}=$ radiographic bone loss; $\mathrm{PD}=$ periodontal pocket depth. $\mathrm{SE}=$ standard error. Bold-face = statistically significant differences between Sámi and non-Sámi in each age group $(p<0.05)$. Statistical analyses were done with ${ }^{\mathrm{a}}=\mathrm{x}^{2}$-test and ${ }^{\mathrm{b}}=$ independent $\mathrm{t}$-test

\section{Author details}

${ }^{1}$ Department of Community Medicine, Faculty of Health Sciences, UiT the Arctic University of Norway, Tromsø, Norway. ${ }^{2}$ The Public Dental Health Service Competence Centre of Northern Norway (TkNN), P.O Box 2406, N-9271 Tromsø, Norway. ${ }^{3}$ Sámi University of Applied Science, Kautokeino, Norway. ${ }^{4}$ Department of Periodontology, Institute of Odontology, The Sahlgrenska Academy, University of Gothenburg, Gothenburg, Sweden.

\section{Reference}

1. Bongo, et al. BMC Oral Health. 2020;20:104. https://doi.org/10.1186/ s12903-020-01098-3.

\section{Publisher's Note}

Springer Nature remains neutral with regard to jurisdictional claims in published maps and institutional affiliations.

Published online: 07 July 2021

Ready to submit your research? Choose BMC and benefit from:

- fast, convenient online submission

- thorough peer review by experienced researchers in your field

- rapid publication on acceptance

- support for research data, including large and complex data types

- gold Open Access which fosters wider collaboration and increased citations

- maximum visibility for your research: over 100M website views per year

At BMC, research is always in progress.

Learn more biomedcentral.com/submissions 